\title{
Cumann na mBan \& Women in Irish Republican Paramilitary Organisations, 1969-1986
}

\author{
Dieter Reinisch \\ European University Institute, Florence, Italy
} Copyright (c) 2016 by Dieter Reinisch. This text may be archived and redistributed both in electronic
form and in hard copy, provided that the author and journal are properly cited and no fee is charged for
access.

\begin{abstract}
Cumann na mBan, the Irish Republican women's organisation. While a number of recent publications have dealt with the first decade of Cumann na $m B a n$, its existence in the second half of the $20^{\text {th }}$ century has largely been neglected by academics. However, women played an integral part in the Republican struggle and many of these women held influential positions in the Irish Republican Movement. With this in mind, the article will discuss the role of Cumann na mBan within the so-called Provisional Republican Movement between 1969 and 1986. Based on 25 Oral History interviews with former members of the women's organisation, the membership structure of the organisation and its activities will be discussed. In particular, the role of women in the Irish Republican Movement will be examined along with a number of other factors which have hitherto been largely underplayed in the historiography of women activists in the Irish Republican Movement. This will provide students and academics with literature for further in-depth research on Cumann na mBan. In essence, the aim of the article is to introduce Cumann na mBan into the historiography of the recent conflict in the North of Ireland.
\end{abstract}

Key Words. Cumann na mBan, Women IRA, Irish Republican Army, Irish Republican splits, Oral History, Northern Ireland Conflict

\begin{abstract}
Cumann nanBan, la organización femenina republicana irlandesa. Mientras un reciente número de publicaciones han tratado sobre la primera década de Cumann na mBan, su existencia en la segunda mitad del siglo XX ha sido ampliamente ignorada por la literatura académica. Sin embargo, las mujeres jugaron un papel fundamental en la lucha republicana y muchas de estas mujeres mantuvieron posiciones de influencia en el Movimiento Republicano Irlandés. Con esto en mente, el artículo trata el papel de Cumann na mBan dentro del llamado Movimiento Provisional Republicano entre 1969 y 1986. A partir de 25 entrevistas de historia orales con antiguas componentes de la organización, se aborda la pertenencia a la estructura y actividades de la organización, examinando el papel de las mujeres en el movimiento republicano lrlandés, junto con un número de cuestiones hasta ahora minimizadas en la historiografía de las activistas femeninas del movimiento republicano irlandés que, sin duda proporcionarán a estudiantes y académicos material útil para investigaciones futuras sobre Cumann na mBan. El objetivo fundamental del artículo es introducir y situar Cumann na mBan dentro de la historiografía del reciente conflicto de Irlanda del Norte.
\end{abstract}

Palabras clave. Cumann na Ban, mujeres en el IRA, Ejército Republicano Irlandés, escisión del movimiento republicano irlandés, historia oral, conflicto Irlanda del Norte. 


\section{Introduction}

The year 2014 marked the centenary of the founding Cumann na mBan, the Irish Republican women's organisation. On April 5, 1914, over 100 women attended a meeting of what was to become Cumann na mBan in Wynn's Hotel, Dublin, presided over by Agnes O'Farrelly. The formation of a Republican women's organisation succeeded the founding of the male-only Irish Volunteers. The organisation played an active role during the 1916 rising, although it had split less than two years earlier into pro- and anti-Redmond factions. ${ }^{1}$ Since members of Cumann na mBan were not allowed to carry weapons, some of their activists joined the ranks of James Connolly's Irish Citizen Army to take an active part in the fighting. The group reorganised following the Rising, establishing hundreds of branches in all 32 Counties of Ireland as well as abroad. Nonetheless, during the Treaty debates, Cumann na mBan split again. Thereupon, the end of the civil war marks the beginning of a weakening of the organisation. A few years later, again, a significant section followed Constance Markievicz and Éamonn de Valera into the 1926-formed Fianna Fail party (Conlon1969; Matthews 2010 \& 2012; McCarthy 2007; Ní Chathmhaoil and Reinisch 2014; Ward 1983: 119-247).

1. John Redmond was an Irish nationalist politician who supported Home Rule, born 1856 in Co Wexford. The nationalist Irish Volunteers (IV) were formed in November 1913 in response to the formation of the unionist Ulster Volunteer Force (UVF). The UVF was committed to resisting home rule, while the IV supported independence. Redmond, fighting in the British House of Commons for Home Rile without partition, was concerned lest the IV should prevent the passing of the third Home Rule Bill. By September 1914, when the Home Rule Act was suspended for the duration of the Great War, membership of IV numbered 180.000. Under those circumstances, Redmond urged the IV to support Britain in the war against Germany "for the freedom of small nations." His call was answered by a majority which became known as the National Volunteers, leaving some 11.000 Irish Volunteers, who opposed involvement in the war. The minority reorganized in October 1914.
While the first decade of its existence was the most active and most influential in the history of Cumann na mBan, the organisation continued to play a significant role in the Republican Movement in later decades. Regardless of their activism in the Republican Movement, the official commemorations marking the centenary of Cumann na mBan neglect the existence of the women's organisation in these later decades. Indeed unsurprisingly, Mary McAuliffe's memorial address at Glasnevin Cemetery ends with the decline of Cumann na mBan in 1923. ${ }^{2}$ Additionally, it has been claimed that Cumann na mBan ceased to exist during the 1970s and 1980s. This claim was first raised in an Irish News article back in 1993 and was subsequently strongly opposed by Cumann na mBan at that time. (Ní Chathmhaoil and Reinisch 2014: 102f.) It was repeated in a report about the Cumann na mBan centenary event in the paper An Phoblacht/Republican News in April 2014. ${ }^{3}$ Certainly, only few researchers acknowledge the contribution by Cumann na mBan to the Republican Movement during the recent conflict in the North of Ireland. One of these is Theresa O'Keefe. In a recently published study on Republican feminism, she argues:

Nonetheless, over the years Cumann na mBan had become an autonomous body, adopting its own constitution and engaging in its own military activities. There remained, however, a high level of cooperation between Cumann na mBan and the [Irish Republican] Army. Often they worked on the same assignment under the direction of the leadership of the IRA (O'Keefe 2013: 92).

While O'Keefe's study is an important contribution to Republican women's activism and Republican feminism in the North of Ireland, it provides little data on Cumann na mBan

2. Mary McAuliffe, Cumann na mBan Memorial Address held at Glasnevin Cemetery, Dublin, on April 2, 2014, http://www.decadeofcentenaries. com/wp-content/uploads/2014/04/Mary-McAuliffeCumann-na-mBan-Glasnevin-speech-.pdf, accessed on: August 6, 2014, 11:30 am.

3. "Cumann na mBan celebrated 100 years on at its birthplace" (An Phoblacht, April 3, 2014). 
itself. In light of this, my article will go further and provide additional data collected through extensive interviews with former and current activists of Cumann na mBan. These data will provide students of contemporary Irish and British history with a clear understanding of who the women were that formed Cumann na mBan during the so-called"Troubles".

The conflict in the North of Ireland is not only the longest war waged in the Western hemisphere since 1945 but, according to John Whyte, the region is "the most heavily researched area on earth" (1991: viii). Although this may be true, Republican women have long been neglected by researchers. As a result, Cumann na mBan during this period is largely missing from literature and most of the books and articles on the recent Irish Republican organisations have not dealt with Cumann $n$ mBan in any depth at all. Contrary, for many years, the role played by women in Irish politics and, in particular, Cumann na mBan was neglected. Lil Conlon's popular account from 1969 was the first history of the organisation. However, her book concludes in 1925. It was not until 1983 that Margaret Ward's influential research Unmanageable Revolutionaries introduced research on Nationalist and Republican women in Ireland. This publication was followed by a study of the conflict in the North of Ireland as a women's war one year later (Fairweather et al. 1984). Recent years have seen a further rise in academic publications about Irish Nationalist and Republican women and their organisations. Still, the vast majority of these publications deal with the formation years of Cumann na mBan and female activists in the early $20^{\text {th }}$ century. ${ }^{4}$ Likewise, recent years have seen the publication of some studies on female activism in the North during the recent conflict. Nonetheless, few of these studies deal with Republican activists; and insomuch as they deal with Republican women, they focus on their prison experience in HMP Armagh. ${ }^{5}$

4. See inter alia: Matthews 2010; 2012; McCarthy 2007; and Paseta 2014.

5. See inter alia: Alison 20009; Banerjee 2012; Corcoran 2006; Keenan-Thomson 2010; Pickering 2002.
Notably, one publication that tries to close this artificial divide into non-Republican activism and militant Republicanism is Begona Aretxaga's study Shattering Silence (1997). Two additional studies also try to close this divide: these are the books by Tara KeenanThomson and O'Keefe. The most recent indepth study of contemporary Republican women is provided in an article by Mia Bloom, Paul Gill, and John Horgan. However, Bloom et al.'s article is intentionally limited to women of the Provisional IRA. ${ }^{6}$ Additionally, the authors wrongly claim Cumann na mBan "was a female-only auxiliary paramilitary force." (Bloom et al. 2012: 64) Furthermore, the authors assert that "Cumann na mBan joined with the newly formed IRA after the 1970 split in the Irish Republican movement" (Bloom et al. 2012: 64); indeed, women were allowed to join the IRA from September 1970 on, though Cumann na mBan has remained a separate organisation up until today (Reinisch 2013). Therefore, the authors are confusing women in the IRA and activists of Cumann na mBan who died as a consequence of their paramilitary activity.

The obstacles in researching Cumann na mBan during the conflict in the North of Ireland are threefold. First, newspaper articles and archival material do not distinguish between women in the IRA, the Official IRA, and Cumann na mBan. For example, the Northern Ireland Office Cutting Files held in the Political Collection of the Linen Hall Library, Belfast, classify all material related to women in the IRA and Cumann na mBan under "Women IRA". Second, from the early 1970s on, Cumann na mBan restrained their craoibh (local branches) from issuing statements and leaflets in order to avoid security service attention. Cumann na mBan activist Saoirse remembers: ${ }^{7}$

Cumann na mBan never published anything. The men always wanted to explain everything to the media. But the women are different. We

6. Henceforth, unless otherwise qualified, IRA will refer to the Provisional IRA.

7. Due to security issues and agreement with the interview partners, all names have been changed to ensure anonymity. 
only published statements when we thought it was really necessary, that was in 1969 and 1986. The women never said anything nor published anything. That was for security reasons. We didn't want to put our members into any danger. This is why only few of our members were arrested. Because the women know not to talk.

This observation is similarly shared by Bloom et al. who write:

Women themselves have been, for the most part, reluctant to meet with and speak to researchers about their experiences. According to one interviewee, there is a sense that women have actually preferred to remain behind the scenes (2012: 81).

Third, Cumann na mBan themselves destroyed internal documents. In the early 1970s women from the North inherited the leadership of Cumann na mBan and this new national leadership from Belfast demanded the transfer of all written accounts from the old leadership, based in the South-West, in particular Cork, Limerick City and North Kerry, to them. This handover of documents occurred in a house near Dublin in approximately the year 1972. Some weeks after this meeting, the old leadership asked about the whereabouts of these documents and they were informed by the new Belfast-based leadership that all documents had been burned for security reasons in a shed near Newry. These documents included clárs, minute books, and statements of the organisation, as Michelle tells. Accordingly, little archival material belonging to Cumann na mBan exists. Thus, Oral History remains the most viable methodology to gather material on the Republican women's organisation.

In light of this, my aim in this article is to provide literature on paramilitary women in contemporary Ireland. To put it differently, Cumann na mBan is the female wing of the IRA and the Republican Movement who have influenced revolutionary movements, guerrilla organisations, as well as terrorist organisations all over the world. Thus, understanding the role and influence of this women's organisation during the conflict in Ireland will make a contribution to understanding the role of women in similar revolutionary movements, paramilitary organisations, and guerrillas from Palestine, to the Basque Country, Sri Lanka, and Colombia. Previously, Reif used a similar approach for women in Latin American guerrilla movements and Hamilton analysed the same for women in the Basque movement ETA (Hamilton 2007; Reif 1986: 147-69). Moreover, since Cumann na mBan supported the formation of the Continuity Army Council in 1986 and their members hold leading positions in so-called "Dissident" Republican movements, an understanding of Cumann na mBan will furthermore serve to consider the role of women in these organisations. ${ }^{8}$

\section{Cumann na mBan, 1960s to 1986}

Founded in 1914 by a few hundred women in Dublin, membership in Cumann na mBan reached 11,000 in the early 1920 s with 838 local branches in 1921. (Ní Cathmhaoil/ Reinisch 2014: 66) During the following decades, the organisation suffered a number of serious splits and was therefore severely weakened. Thus, by 1950 , the organisation consisted of merely a handful of Republican veterans, called " 12 Apostles", referring to the strength of the organisation (Ní Cathmhaoil/ Reinisch 2014: 66). Among those women was Margaret Buckley who served as Sinn Féin President from 1937 to 1950 and as VicePresident from 1950 to 1958 (Ní Cathmhaoil/ Reinisch 2014: 69). Nonetheless, following the failed Operation Harvest, ${ }^{9}$ Cumann na mBan started to reorganise by recruiting for its youth wing Cumann na gCailiní in the early 1960s.

In autumn 1968, the General Army Convention of the IRA decided to accept women as members of its organisation (Reinisch 2013: 116). This was in reaction to Cumann na mBan's public criticism of the leadership at the annual Bodenstown Commemoration earlier that year. In the course of the coming year, infighting over the question of the future programmatic and military strategy of the Republican Movement led to a split into a Marxist faction, led by Cathal Goulding, calling itself the "Official

8. See inter alia: Alison 2009; and Ní Chathmhaoil and Reinisch 2014: 95-110.

9. "Operation Harvest" was the codename for an IRA campaign against British presence in the North. Launched in December 1956, the campaign received little support and was called off in 1962. 
IRA" and a Nationalist one which became known as the "Provisional IRA."Cumann na mBan activists played a crucial role in the events leading to this split. Accordingly, in his analysis The Irish Troubles, J Bowyer Bell writes:

The women's organisation Cumann na mBan was particularly recalcitrant. Republican women had long been ideologically most pure, most militant. They sniffed out the politics and opposed it. Why had so many died? Not for politics (Bell 1993: 144).

Cumann na mBan activists, for instance, were involved in the Barnes and McCormack Repatriation Association. The committee's secretary was Caitlín Uí Mhuimhneacháin, a Cumann na mBan veteran from the 1940s and a staunch defender of abstentionism. ${ }^{10}$ The committee rapidly developed into a centre for those opposed to the Goulding-leadership and their followers (Ní Cathmhaoil/Reinisch 2014: 76; White 2006: 144).

At the height of the debates which led to the split in 1969, the male IRA Army Council lost control over Cumann na mBan. At the Wolfe Tone Commemoration in Bodenstown 1968, the women's organisation had refused to march if communist flags were carried. The following year, Cumann na mBan again refused to participate in this commemoration. Instead, they issued a statement explaining the situation from their perspective and saying "Cumann na mBan will continue to uphold the ideals and traditions of true Republicans as it has done since its foundation" (Ní Cathmhaoil/ Reinisch 2014: 76f). The women explained that, at its convention in 1967, the organisation had decided not to participate in any parades where communist flags are carried. Hence, Cumann na mBan branches in Cork and Belfast were

10. Abstentionism is standing for election to a deliberative assembly while refusing to take up any seats won or otherwise participate in the assembly's business. It differs from an election boycott in that abstentionists participate in the election itself. Abstentionism is an idea that was discussed in the Irish independence movement after the Act of Union in 1800, that specified that the whole of Ireland should be ruled directly from London. The tactic had been used by Sinn Féin since its formation in 1905 . banned by the leadership of the Republican Movement from using Republican premises such as Sinn Féin offices. The reason given to Cumann na mBan by other Republicans was that they were no longer recognised as an official part of the Republican Movement. The May issue of the United Irishman had reported that members "of the defunct women's organisation" had participated in Easter Commemorations in Limerick (Ní Cathmhaoil/ Reinisch 2014: 76f).

Whereas the majority of Cumann na mBan broke with the Republican Movement, not all local branches followed this organisational line. Notably, a majority in the Dublin Branch of Cumann na mBan supported the Gouldingleadership and a contingent from Dublin marched under their own flag at Bodenstown in 1969, which put them outside the women's organisation. The wife of then Sinn Féin President Tomás Mac Giolla who went on to become President of Official Sinn Féin and later the Worker's Party, Máire Mac Giolla (nee Mary McLoughlin), had been Officer-inCommand of Cumann na mBan in Dublin prior to 1969. ((Ní Cathmhaoil/Reinisch 2014: 76f) Following the implementation of the Republican split in 1969, Cumann na mBan aligned itself to the newly-formed Provisional Army Council. In his memoirs, IRA founder Seán MacStiofáin writes:

Representatives met the Executive of Cumann na mBán (sic), the women's section of the Republican Movement, an organisation which over the years never had much time for deviations from the goal of total Irish freedom. Just as it had unanimously opposed the partitionist Treaty of 1921 , its present-day Executive now unanimously decided to accept the authority of the Provisional Army Council. The break in the movement was now complete (1975: 150).

Although MacStiofáin correctly remembers a meeting between Cumann na mBan and the Provisional Army Council following which the former pledged allegiance to the latter, the decision to accept women in the IRA was reconfirmed by the same Army Council at a meeting held on the last Saturday in September 1970. ${ }^{11}$ Conse-

11. Interview with former member of PIRA Army Council, April 7, 2011, Limerick. 
quently, women were first recruited by the IRA in Belfast, which led to fierce criticism by activists of the women's organisation Cumann na mBan itself (Reinisch 2013: 121-9).

While several hundred women became involved in Republicanism following the outbreak of the war in summer 1969, little is known about the contribution of Cumann na mBan during this phase. What is known is that in the early 1970 s, the organisation elected a new leadership and adopted a military structure (Ní Cathmhaoil/Reinisch 2014: 84). Furthermore, military titles were introduced and on Saturday, October 23, 1971, Maura Meehan, aged 30, and her sister Dorothy Maguire, 19, were shot dead in their car by the British Army while driving through the Lower Falls area of Belfast. Both were members of Cumann na mBan and the first two members of the organisation to die during this phase of the conflict (Ní Cathmhaoil/Reinisch 2014: 86). ${ }^{12}$ The most active period of Cumann na mBan were the years leading to the hunger strikes in 1980/81. This was a direct result of the growing membership since the early 1970s and the restructuring of the organisation around the same time. For instance, when British paratroopers disbanded the IRA unit in Ardoyne, North Belfast, in the early 1970s, it is reported by two Cumann na mBan members from this area, Saoirse and Angela, that the women's organisation kept the fight going for more than six months until the IRA unit could be reorganised.

The role of women in the Republican Movement changed during the 1970s. There were no underlying internal, but primarily external reasons responsible for the moves that sparked these developments. By the beginning of the conflict there was a rapid increase in the membership of Cumann na mBan. At the same time a large proportion of the male Nationalist activists were interned. Consequently, the women had to take the men's places and subsequently proved to be able to fill the male roles in the family, at workplaces, in politics and in the Republican organisations. Furthermore, the Provisional Republican Movement

12. For accounts see also: Fitzsimons 1999: 25f.; and MacStiofáin 1975, 217 f. was certainly a socially and morally conservative organisation in its early days. At the same time, many of the young women attracted to it were not immune to the developments in radical ideas and politics in the 1960s. In the first years of the conflict in the North, women engaged in new elements of political activism within the Nationalist community, both inside and outside the Republican Movement. Keenan-Thompson explains:

Earlier events of 1968/9 had helped lay the groundwork for a change in the structure of the gender regime by allowing women the space to enter into political discourse. Women such as Bernadette Devlin, Edwina Stewart and Ann Hope had quickly risen to become political figures and role models for this new type of expression, but a feminist consciousness did not surface during this period due to a variety of factors, including the intensity of unfolding sectarian warfare and an ensuing sense of tribalism (2010: 214).

Thus, while some "groundwork for a change" had been laid, a feminist consciousness did not come to the fore in those early years and disagreeing with the male leadership's conservativism was not necessarily, in the eyes of these young women, disloyal.

The developments in the early 1970s, among these the mass internment of men, the influx of women into the Republican Movement, as well as the reorganisation of Cumann na mBan from auxiliary force into a women's army, empowered women as equal political and military actors in their Nationalist communities in the North. This regained strength of the orthodox Republican women's organisation Cumann na mBan was met with opposition from less orthodox circles in the Republican Movement. When Séamus Twomey, then Chief-of-Staff of the IRA, was arrested in 1977 in Dublin, a document outlining the proposed reorganisation of all Republican organisations was seized. This document stated, among other things, that Cumann na mBan would be dissolved, its best elements would be incorporated into IRA cells and the rest would be going towards the civil and military administration (Maillot 2005: $108 \mathrm{n}$ 4).

This planned reorganisation of the IRA 
structure was not only a military necessity but also foreshadowed the political frictions developing between the older Southern-based leadership of Sinn Féin and a younger, local IRA leadership in the North. These Northern activists were willing to compromise some of the longstanding principles of the Republican Movement. Finally, it were these developments that resulted in the 1986-split of the Republican Movement. At the same time, Cumann na mBan had regained some of the strength and a more powerful position within their movement than at any time since 1923 . However, while recruiting a significant number of young, active recruits, the organisation was still lead by staunch Republican women who continued the orthodox tradition. KeenanThompson argues that joining Cumann na mBan "was an attractive option for some republican women" for three essential reasons: First, the organisation maintained an unbroken continuity that dated back to April 1914; second, the group provided essential tasks during the on-going armed campaign; and third, "joining a female-orientated group allowed women an amount of flexibility with their commitments with the movement and within their homes" (2010: 228). To be sure, it was this strength combined with the orthodox tradition that threatened the growth of new approaching ideas in the Republican Movement. The young, unorthodox Northerners feared the stance Cumann na mBan could take against them, as the organisation did during the 1969-split. Thus, this newly approaching male Sinn Féin and IRA figures from the North, mainly from Belfast and Derry, singled out Cumann na mBan as their first counterpart in the Republican Movement that needed to be marginalised. In other words, while regaining strength, the Republican women were making enemies within their own movement that tried to marginalise them in order to silence their orthodox political viewpoints.

Cumann na mBan tried to oppose this marginalisation; however, in 1981, Sinn Féin formed a separate Women's Department to further weaken the political position of Cumann na mBan in the movement. Indeed, the women directly organised in Sinn Féin were easier to control by the male leadership than those organised in a separate organisation. According to their orthodox political positions, activists of Cumann na mBan were among those opposed to the new leadership, elected at the 1983 Ard-Fheis (AGM) of Sinn Féin, and the dropping of abstentionism at the Sinn Féin Ard-Fheis in November 1986. Following the walkout of those who opposed the new programmatic direction, the group constituted as Republican Sinn Féin, led by veteran Republicans such as Ruairí Ó Brádaigh, Joe O’Neill, Dáithí Ó Conaill, and Des Long. Among the Head Office staff of the newlyformed group was also Cumann na mBan veteran Líta Ní Chathmhaoil (White 2006: 312f). The first issue of their paper Republican Bulletin, dated November 1986, carried a message of support from Cumann na mBan saying:

Our stance today is not something new for us in Cumann na mBan. One has only to look at the Treaty debates of 1922 and our contribution to them. Again in 1932 when Republicans sided with de Valera on the promise that that he would close the jails, we in Cumann na mBan stood by the Republic. Also in 1948 and in 1968 we remained true to that fundamental principle. ${ }^{13}$

Following the split of the Republican Movement in 1986, Cumann na mBan remained intact, though it lost a significant section of its members. In 1993, the women's organisation had active craoibh (local branches) in Belfast, Dublin, Limerick, Cork, and Galway, as well as members in areas such as Dundalk, Kildare or Donegal. Three years later, Josephine Hayden from Co. Waterford, a member of the Dublin unit of Cumann na mBan, was sentenced to six years imprisonment on firearms charges. Finally, in December 2011 the British government listed Cumann na mBan as a "Proscribed Terrorist Organisation" under the Terrorist Act passed in 2000 (Ní Cathmhaoil/Reinisch 2014: 99-104).

\section{Interviewing Irish Republican Women: The Data}

Active or former members of Cumann na mBan or its youth wing Cumann na gCailiní

13. Cumann na mBan Statement (Republican Bulletin, November 1986). 
were interviewed for this research. ${ }^{14}$ The motivations of the interviewed women who joined Cumann na mBan before 1969 are different from those of women who joined after 1969. All interviewees who joined the Republican women's organisations before 1969 had a Republican family background. This is contrary to the situation among the recruits after 1969. Among these women, less than half of them had a Republican background. Indeed, all interviewed Republican activists from the southern Republic who joined not only before 1969 but also after 1969 had a Republican family background. Contrary to the pre-1969 period, girls and women joined Cumann na mBan as a reaction to the conflict in the North in the 1970s. In other words, there were fewer ideological reasons for joining Cumann $n a$ mBan after 1969. Instead, they joined because of the outbreak of the armed conflict and the British military presence on the streets. Some of the women explained their radicalisation through specific events during the first years of the conflict. Andrea, for example, said the first event of the Troubles she remembers was Bloody Sunday in Derry. She subsequently joined the Cumann na gCailiní branch in the city due to her opposition to the British army and the shooting of protestors on that day. Women from the Republic of Ireland similarly quote the events on Bloody Sunday as the reason for their radicalisation, such as Brigid:

I was working in Jersey at that time. I came home to Ireland and saw all these things from the 6 Counties on the news. Then came Bloody Sunday and I joined the Republican Movement. I joined Cumann na mBan because I thought it is my duty to defend the people up there.

Similar experiences are recorded by O'Keefe. She quotes one Cumann na mBan member saying:

I was watching the injustice (...) on TV. I was away working in [a place outside Ireland] at that time and I was watching it happen on TV. My conscience was at me that I wasn't doing something. I eventually came home and got involved (O'Keefe 2013: 58).

14. For a detailed description of the interviews, data, and the biographies of the interviewees, see: Reinisch 2013; and Reinisch 2017.
Another Cumann na mBan member says:

I was always aware, all of my life, of politics. However, in 1969, when the Brits moved in to murder the nationalist community I thought it was time to be involved. Only for the Brits here I wouldn't be involved at all (O'Keefe 2013: 58).

Another key event mentioned in the interviews is the introduction of internment. Similar to Bloody Sunday in Derry, the introduction of internment in summer 1971 was a cause for recruitment. Indeed, the majority of the young recruits from the early 1970s had either their father or their brothers interned. Saoirse was among the thirty-three women interned, whereas about one thousand two hundred men were interned. Altogether, the first few years of the conflict saw an enormous increase of the membership numbers of all Republican organisations, in particular the women's organisations Cumann na mBan and Cumann na gCailíní. Yet women also became active in other branches of the Republican Movement, such as prisoners' support groups or commemoration committees. Eimear, for example, went to the office of Sinn Féin in Dublin and applied for membership of the Republican party. However, it was Sinn Féin who passed on her contact details to Cumann na mBan who then approached her and she became a leading member of Cumann na mBan in the Republic of Ireland.

\subsection{Membership Numbers in Belfast in Early 1970s}

While the membership numbers of Cumann na mBan grew rapidly in the early 1970s, an exact estimation has yet to be made. As mentioned, Cumann na mBan activists were called "the 12 Apostles" referring to their membership strength in the 1950s. This situation changed after 1969. Still, due to the lack of sufficient data available, predication on the overall strength of Cumann na mBan and its local branches is not possible at present. Memoirs of Irish Republicans give only isolated insight in the membership strength of various Republican organisations. Belfast IRA member Gerry Bradley, for example, said that in 1971 there were "at least fifty members of the Fianna and Cumann na gCailíní, in Unity Flats alone, half of the boys and girls my age 
Flats alone, half of the boys and girls my age in the district" (Bradley/Feeney 2011: 42). For 1972, Bradley estimated that there were "about thirty trained IRA members, men and women, in $G$ company, supported by about fifty auxiliaries and forty to fifty Fianna and Cailíní, aged fourteen to sixteen" (Bradley/Feeney 2011: 49). Moreover, he remembered the numbers in 1973 were "about twenty IRA volunteers in the company, mainly from Unity, but a couple from the New Lodge. Altogether, with auxiliaries and Fianna and Cumann na gCailíni (...) a hundred plus individuals" (Bradley/Feeney 2011: 106).Angela, who was active in Ardoyne, said that there were "20 members of Cumann na mBan in Belfast" in 1969. Saoirse also says the number of female activists in Belfast was "very low" in 1969 "but there were also very few in the [Irish Republican] Army". Similarly, Megan, who was also active in Ardoyne, said that, in 1970, there were "20, 25 [in Cumann na mBan] and a further fourteen in Cailinı'. If these numbers given for Belfast in 1969 and 1970 by women themselves are compared with the numbers for the small area in North Belfast, Unity Flats and New Lodge, in 1971, 1972 and 1973 as given by Bradley, we clearly see the increase in activists during these early years of the conflict. Eimear from Dublin also remembers the influx of recruits:

When the women had to take over everything during internment, I mean, not just the ordinary women who banged the bins, they also did other things, and there was a heavy increase in membership. Well, you could see it in all areas of the Republican Movement. I remember there were more than 40 people who joined the [Provisional] Sinn Féin Cumann I was a member of. That was after internment. And I suppose even more people joined after Bloody Sunday. But look, these recruits - the people don't stay for long with the movement. But when you have these waves of applications, there is always a nucleus that stays, and the rest keeps being a supporter.

This account from Eimear shows that the membership of the various branches of the Republican Movement dramatically grew following particular events that were interpreted by a section of the Irish people as an attack on the whole Nationalist community in the North (internment) or were widely broadcast and discussed (Bloody Sunday, hunger strikes). However, only a small number of these new recruits actually became longterm, active Republican. Indeed, they majority drifted away from politics soon. Nonetheless a small number of these recruits stayed with their new organisations and thus the membership of Cumann na mBan and other Republican organisations steadily increased through-out the 1970s and 1980s.

\subsection{Fields of Activities}

Republican women were involved in various fields of activities, both politically and militarily. Before 1969, and in particular in the Republic of Ireland, the activities of Cumann na mBan activists included recruiting, smuggling, training, raising funds and organising safe-houses for Republican on the run, so-called billets. Yet, when Cumann na mBan introduced a military structure and military titles in $1971 / 72$ due to the intensifying conflict in the North, women also joined IRA Units, acting as Cumann na mBan members under the guidance of the IRA Army Council (Reinisch 2013). O'Keefe explains these emerging circumstances:

Women who joined Cumann na mBan in the early 1970s were not involved in the same work as men in the movement and were excluded from combat. Their role in Cumann na mBan appeared to be primarily a supportive one. With no representation on the IRA Army Council women were not playing a role in determining the nature and extent of their participation. The women of Cumann na mBan often acted on the direction of the Army Council, thus placing them in a relatively powerless position, as 'ladies in waiting' (2013: 91).

Indeed, Cumann na mBan has always been subordinated to the seven-volunteers strong, only-male Army Council of the PIRA, a claim that has previously been stressed by $\mathrm{Ed}$ Moloney and Bell (Bell 2000: 129f; 2002: 55). While the majority of the interviewed women argued similarly to O'Keefe's findings, a section of the activists paint a different picture. Liz, active in the Lower Falls area of West Belfast, remembers that the IRA unit in Lower Falls consisted during internment of three women and two men. She tells about her own 
role between IRA and Cumann na mBan:

I was in both organisations. I was quartermaster in the Army and still in Cumann na mBan. This led to tensions within Cumann na mBan. I was sent to Dublin and they accused me of acting unauthorised. I didn't know that I had to ask for permission. I didn't know that I had to do it. I only did my job. (...) We all fought for the same thing.

It is unknown if she was disciplined or not by Cumann na mBan for her behaviour. Nonetheless, it is noteworthy that she had to report to Dublin while the leadership of Cumann na mBan was based in Belfast. However, this account furthermore shows that it was indeed possible for women to gain leadership positions within the IRA. Not to mention that Lower Falls was also the area where on October 23, 1971 the first two Cumann na mBan members were shot during the conflict (Ní Cathmhaoil/Reinisch 2014: 86). Meanwhile, the local IRA in Ardoyne was reorganised by the first Commanding Officer of the IRA in Ardoyne, Martin Meehan, and the then chairperson of the local Sinn Féin Cumann, Mary McGuigan, also a member of the Belfast craobh of Cumann na mBan (Graham 2008: 45). Throughout the 1970s, the local Cumann na mBan organisation had a significant representation in IRA operations in Ardoyne. Dolours, who was active in West Belfast, explains the relationship of Cumann na mBan and the IRA on active service:

If ASU [Active Service Units] were erected and the army needed volunteers they asked women in Cumann na mBan to support them. If a woman was in an ASU she was not allowed to speak to anyone about their activities. Only if there were problems, for example in operations if there is only one way in but none out and the member was afraid of being shot dead, then they could report to Cumann na mBan and we then discussed it with the army.

According to the information obtained by the interviews, the fields of activities of the Cumann na mBan members can be classified in three categories. Category A includes women who focused on political and legal work such as selling papers, collecting money for prisoners' dependents funds, liaison between the movement and the imprisoned Republicans, carrying messages, recruitment for Cumann na mBan in the Republic of Ireland and for Sinn Féin in the North, or training and drilling Cumann na gCailiní in the Republic. Additionally, some of them were responsible for organising safe houses in the Republic for IRA members on the run. The women organised these safe houses, brought clothes, food, literature, and cigarettes to the Republicans staying in these houses. Furthermore, intelligence work was widespread among these women. Ashley from Dublin remembers how she collected information on An Garda Síochána, the police force of the Republic of Ireland, Special Branch officers in the 1960s. She describes this procedure in the following words:

One thing we were always taught to do: To keep our eyes and ears open. And, I don't suppose anybody hears me, but - ehm - we, well, everyone did this, and that would be part of my details as well, note down Special Branch car numbers, descriptions of the men who would stop you and talk to you. If you could see the [Police ID] card when they flash it on you, you put the name down, you know. Sometimes they just flash it. Even today they just flash it and you nearly had to hold the hand on it to see it. They are just flashing it in front of you. But that was part of it. And then during the mid$60 \mathrm{~s}$, that was more or less what it was there. Others that were older than me were doing more important things like me. [They were] preparing for the future.

Category B is formed by women who did the same activities outlined in Category A plus additional clandestine work such as transportation of arms, ammunition, explosives, and bombs hidden or produced in the Republic, and later couriered to the North. The Northern areas where Cumann na mBan members from the Republic were most active were North Louth, South Armagh, Fermanagh and South Derry. Republican women brought the material from places in the Republic into these areas where they were collected for attacks by IRA members from the North. A few of these Cumann na mBan members were furthermore active as recruits and organisers for new Cumann na mBan branches in the North. Other women included in this category 
organised training camps in the Republic for IRA members. Most of the training camps organised by Cumann na mBan took place in the southern counties of Kerry and Cork. This was also the area were Cumann na mBan was best organised before 1969 .

Finally, Category $\mathrm{C}$ includes women who were actively involved in open warfare in the North. Una who was active in Belfast and Dundalk remembers transporting arms and bombs to Belfast in the early 1970s:

I was coming by bus from Dublin. It was raining in Belfast and I had a big bag with me I could hardly carry, it was too heavy for me. When I walked up Grosvenor Road, coming from City Centre I was stopped by a young British soldier. I thought: 'Oh my God, that's it.' I told him I had my laundry with me and that I was on my way home. He took the bag off me and said he would help me to carry it home. We walked there, talking about the weather and stopped at Springfield Road and I took a taxi.

The soldier waved her good-bye and was left standing on the pathway until the black taxi arrived. What he did not know was that the woman was a member of Cumann na mBan not carrying laundry with her. In the bag there was a bomb: "He didn't know what he was doing. This British soldier carried the bomb the whole way from City Centre up to Springfield Road." This situation illustrates that women could use their role given by society as weak and helpless in order to support the war-efforts of the male IRA.

\section{Conclusions}

To conclude, I will summarize the three main reasons for the changing role of Cumann na mBan both within the Republican movement as well as in Irish society in the 1970s.First, the appearance of new recruits. Before 1969, Cumann na mBan was an organisation uninvolved in any armed struggle. These Republican women were known to An Garda Síochána Special Branch in the Republic of Ireland and the Royal Ulster Constabulary in the North. Consequently, when the conflict started, these women could not join a clandestine army. Instead, these women continued with their open work. At the same time Cumann na mBan experienced an increase in membership. When Cumann na mBan elected a new leadership in 1970/71 and adopted a military structure for its organisation, it was these new, younger and previously unknown recruits who moved into military roles, either taking charge of arsenals in the Republic, couriering arms and bombs, or participating in open warfare. These new roles performed by Republican women did not go unnoticed by Republican men. In his memoirs, IRA founder Seán MacStiofáin writes:

However, in the early 'seventies, a selected number of suitable women were taken into the IRA and trained. Some of the best shots I ever knew were women. So were the smartest intelligence officers in Belfast (MacStiofáin 1975: 218).

Second, the motivations for joining the organisation changed. The women who joined the Republican Movement in the 1960s or earlier were attracted to Republicanism by political ideology and biographical continuity while the majority of the activists recruited after 1969joined to fight British soldiers. However, the ideological aspect of the pre1969 recruits becomes evident in later years, while the younger activists focused on military involvement instead of ideological purity and Republican principles. Their main objective was to be part of a broad, active and wellequipped organisation. Accordingly, some of them developed progressive, even feminist political views. One of these younger recruits was Andrea who explains the situation in Derry during the 1970s in following way:

I wanted to fight a war. I wanted to take an active part in it, do the same thing the men did. (...) My own experiences led me to the decision that the structure of Cumann na mBan, as important as it was, you know, also Cumann na mBan and the [Irish Republican] Army didn't play an equal role. Well, that cannot be said about all their members, I mean, they had a supportive role. And this role should have been dropped, but instead they were just there to strengthen the army structure, you know.

On the other hand, there are the Republican women who joined Cumann na mBan in the 1960 s or earlier. These women had ideological and biographical reasons to become active Republicans. This became evident during the Republican split in 1986 when a vast majority 
of these pre-1969 recruits supported the walkout of veteran Republicans from the Sinn Féin Ard-Fheis. Ashley is a Cumann na mBan veteran who joined Cumann na gCailíni as a young girl in the mid-1940s. In her interview she explained the political motivation of the Republican women of her generation. When giving her answer, by the same token she gives her interpretation of Republican history:

Now, Cumann na mBan never deviated the slightest, they were on the same road up until now. No matter where the Army went or where Sinn Féin went, they were always there. And when they read the situation, they aligned themselves with those who were going the right way. And that's where they are still. (...) Because they were going on that road since 1916.

In particular, the aspects of "biographical continuity", "family background on recruitment to high-risk activism", and the recruitment period influencing activism are well-documented (Della Porta 1988, 1992). In regard to North of Ireland, these phenomena demonstrated above correspond with Robert White's findings about post-recruitment activism of Irish Republicans (White 2007).

Third, the change towards more military involvement was encouraged by internment in August 1971 because men were interned and women had to take their roles in household, workplace and politics. Furthermore, due to events such as internment and Bloody Sunday more women aimed to become directly involved in the armed struggle. Cumann na mBan reacted to this situation by adopting a more military outlook and a new structure. Furthermore, the Northern women took over the leadership of the organisation and the position of President was renamed to Officerin-Command.

To sum it up, the role of Cumann na mBan changed in the course of the conflict in the North of Ireland. To be sure, Cumann na mBan was an auxiliary force pre-1969, collecting money, supporting the prisoners and organising safe houses and its role hardly changed in the southern Republic, hence, all the long-term activists in that region continued with this work. Conversely, in the North, Cumann na mBan developed into a women's army, supported by younger recruits from the south, especially the Dublin area, who were sent "on active service" to the Border Counties, South Armagh and Derry. As seen in the paper, post-1986 Cumann na mBan survived due to activists from the Republic who had joined the Republican Movement before the split in 1969/70. Moreover, the role of Cumann na mBan during the split in 1986 made it possible for some women to gain leading positions in the political and military wing ${ }^{15}$ of this new "Dissident" Republican movement.

This article on Cumann na mBan provides a case study of similar developments in other national liberation movements. The sexual revolution, Marxist influence in post-colonial movements and feminism in the post-1968 era, empowered women in political organisations. However, while considering themselves as progressive liberation fighters, members of national, anti-colonial organisations were often raised in a conservative social environment, thus representing these conservative values within their organisations. Under those circumstances, women had to fight for equal status in these organisations. It was not until the 1970s and 1980s that women were accepted as fighters in the main anti-colonial movements in countries like Kurdistan, Palestine, the Basque Country, or Sri Lanka. This case study on the Irish Republican women's organisation Cumann na mBan outlines the fight for women's equality in the Irish Republican movement during this period. This was a struggle that was fought by other women in similar organisations worldwide. While women are recently used as the images of the militant struggles by progressive Palestinian forces such as the PFLP or the Kurdish guerrillas fighting Daesh in Syria, this article outlines that the struggle for equal roles of women's in these paramilitary organisations lasted in certain cases a few decades; in some cases it still did not succeed.

Acknowledgments. I thank Laura Lee Downs (EUI), Patrick McDonagh (EUI), Nicole

15. Alison 2009: 187; She notes that "it is notable, however, that on the occasions when CIRA [Continuity IRA] has held press conferences or photo opportunities for local press there have frequently been female figures visibly present". 
Owtram (EUI), Javier Ruiz Soler (EUI), Robert W. White (IUPUI), Victoria Witkowski (EUI) and the anonymous reviewers of Estudios Irlandeses for their very useful comments; as well as Líta Ní Chathmhaoil (Dublin), Josephine Hayden (Dublin/Waterford), and Geraldine Taylor (Belfast) for assisting this research. They are not responsible for any errors or the opinions expressed.

Funding. This work was supported by the Austrian Agency for International Cooperation in Education and Research under the Erasmus-Exchange Programme; and the Celtic Research Trust (Isle of Man).

\section{Works Cited}

Alison, Miranda H. 2009. Women and Political Violence: Female Combatants in Ethno-National Conflict. London: Routledge.

Aretxaga, Begoña. 1997. Shattering Silence: Women, Nationalism and Political Subjectivity in Northern Ireland. Princeton: Princeton University Press.

Banerjee, Sikata. 2012. Muscular Nationalism: Gender, Violence, and Empire in India and Ireland, 1914-2004. New York: NYU Press.

Bell, John Bowyer. 1993. The Irish Troubles: A Generation of Violence, 1967-1992. New York: St. Martin's Press.

2000. The IRA, 1968-2000, Analysis of a Secret Army. London/New York: Taylor Francis.

Bloom, Mia, Paul Gill, and John Horgan. 2012. "Tiocfaidh ar Mná: Women in the Provisional Irish Republican Army." Behavioral Sciences of Terrorism and Political Aggression 4, no. 1. 60-76.

Bradley, Gerry, and Brian Feeney. 2011. Insider: Gerry Bradley's Life in the IRA: Dublin: O'Brien Press.

Conlon, Lil. 1969. Cumann na mBan and the women of Ireland, 1913-25. Kilkenny: Kilkenny People.

Corcoran, Mary S. 2006. Out of Order: The Political Imprisonment of Women in Northern Ireland, 1972-98. Devon: Willan.

Della Porta, Donatella. 1988 "Recruitment Processes in Clandestine Political Organizations: Italian Left-Wing Terrorism." International Social Movement Research 1. 155-69.

, Donatella. 1992. "Biographies of Social Movement Activists: State of the Art and Methodological Problems." Studying Social Movements. 168-93.

Fairweather, Eileen, Roisin McDonough, and Melanie McFadyean. 1984. Only the Rivers Run Free. Northern Ireland-the Women's War. London: Pluto Press.

Fitzsimons, Lily. 1999. Liberty Is Strength: Thirty Years of Struggle. Belfast: np.

Graham, Joe. 2008. Show Me the Man: The Official Biography of Martin Meehan. Belfast: Rushlight.

Hamilton, Carrie. 2007. Women and ETA: The Gender Politics of Radical Basque Nationalism. Manchester: Manchester University Press.

Keenan-Thomson, Tara. 2010. Irish Women and Street Politics 1956 - 1973. Dublin: Irish Academic Press.

MacStíofáin, Seán. 1975. Revolutionary in Ireland. London: Cremonesi.

Maillot, Agnès. 2005. New Sinn Féin: Irish Republicanism in the Twenty-First Century. London: Routledge.

Matthews, Ann. 2010. Renegades: Irish Republican Women, 1900 - 1922. Cork: Mercier. 2012. Dissidents: Irish Republican Women, 1923 - 1941. Cork: Mercier.

McCarthy, Cal. 2007. Cumann Na mBan and the Irish Revolution. Cork: Collins.

Moloney, Ed. 2002. A Secret History of the IRA. New York: W.W. Norton.

Ní Chathmhaoil, Líta, and Dieter Reinisch. 2014. Cumann Na mBan. 100 Years Defending the Republic. Dublin: Cló Saoirse.

O’Keefe, Theresa. 2013. Feminist Identity Development and Activism in Revolutionary Movements. New York: Palgrave Macmillan.

Paseta, Senia. 2014. Irish Nationalist Women, 1900-1918. Cambridge: Cambridge University Press.

Pickering, Sharon. 2002. Women, Policing, and Resistance in Northern Ireland. Belfast: Beyond the Pale Publications.

Reif, Linda L. 1986. "Women in Latin American Guerrilla Movements: A Comparative Perspective." Comparative Politics 18, no. 2. 147-69.

Reinisch, Dieter. 2013. "Cumann Na mBan and the Acceptance of Women in the Provisional IRA: An Oral History Study of Irish Republican Women in the Early 1970s." Socheolas 5.1, 115-34.

. 2017. "Frauen in der Irisch-Republikanischen Bewegung nach 1969. Ein Beitrag zu Gender Studies und Oral History in der Keltologie". Keltische Forschungen 8, accepted.

Ward, Margaret. 1983. Unmanageable Revolutionaries: Women and Irish Nationalism. London: Pluto. 
White, Robert W. 2006. Ruairí Ó Brádaigh. The Life and Politics of an Irish Revolutionary. Bloomington: Indiana University Press.

. 2007. “'I'm Not Too Sure What I Told You the Last Time': Methological Notes on Accounts from High-Risk Activists in the Irish Republican Movement." Mobilization: An International Quarterly 12, no. 3. 287-305.

Whyte, John. 1991. Interpreting Northern Ireland. Oxford: Oxford University Press.

\section{Interviews}

Andrea is a (former) member of Cumann na mBan from Derry City. Interviewed on December 9, 2009, Belfast. Angela, (former) member of Cumann na mBan from Dundalk; March 5, 2010, Belfast.

Ashley, (former) member of Cumann na mBan from Dublin; November 25, 2009, Dublin.

Brigid, (former) member of Cumann na mBan from Waterford; December 2, 2009, Dublin.

Dolours, (former) member of Cumann na mBan from West Belfast, December 15, 2009, Belfast.

Eimear, (former) member of Cumann na mBan from Dublin; December 11, 2009, Dublin.

Liz, (former) member of Cumann na mBan from Lower Fall, Belfast; March 1, 2010, Belfast.

Megan, (former) member of Cumann na mBan from Ardoyne, Belfast; March 5, 2010, Belfast.

Michelle, (former) member of Cumann na mBan from Limerick; March 30, 2010, Limerick.

Saoirse, (former) member of Cumann na mBan from Belfast; April 8, 2010, Belfast

Una, (former) member of Cumann na mBan from Belfast and Dundalk; March 5, 2010, Belfast.

(Former) member of IRA Army Council; April 7, 2011, Limerick.

Received 1 December 2015 Last version 6 January 2016

Dieter Reinisch is Researcher at the Department of History \& Civilization, European University Institute, Florence, Italy. At the EUI, he is organiser of the Working Group " 'These Islands': Ireland, Britain, and the Empire". Previously, he lectured in Irish History at the University of Vienna, Austria. Among his forthcoming publications is a special edition of Studi Irlandesi "Resistance in Modern Ireland". 